\title{
THE DILEMMA OF TRADITIONAL AND 21ST CENTURY PASTORAL MINISTRY: MINISTERING TO FAMILIES AND COMMUNITIES FACED WITH SOCIO-ECONOMIC PATHOLOGIES
}

Author:

Gordon E. Dames ${ }^{1}$

\author{
Affiliation: \\ ${ }^{1}$ Department of Practical \\ Theology, University \\ of the Free State, South \\ Africa
}

\section{Correspondence to:}

Gordon Dames

email:

damesge@ufs.ac.za

Postal address:

PO Box 339, Bloemfontein 9300, South Africa

\section{Keywords:}

missional pastoral

ministry; socio-

economic and systemic

pathologies; maintenance ecclesiologies; transversal hermeneutics; povertystricken families and communities; liberation and empowerment

\section{Dates:}

Received: 16 Mar. 2010

Accepted: 03 Sept. 2010

Published: 23 Nov. 2010

How to cite this article: Dames, G.E., 2010, 'The dilemma of traditional and 21st-century pastoral ministry: Ministering to families and communities faced with socioeconomic pathologies', HTS Teologiese Studies/ Theological Studies 66(2), Art. \#817, 7 pages. DOI: 10.4102/hts.v66i2.817

This article is available at:

http://www.hts.org.za

\section{Note:}

This article was initially presented as a paper at the Joint Conference of Academic Societies in the Fields of Religion and Theology, Stellenbosch University, 23 June 2009.

(c) 2010. The Authors. Licensee: OpenJournals Publishing. This work is licensed under the Creative Commons Attribution License.

\section{ABSTRACT}

A holistic pastoral methodology is sought in transforming the socio-economic and systemic pathologies of poor families and local communities. Missional pastoral ministry is proposed from a critical hermeneutical and contextual perspective for the empowerment and liberation of people living with complex and multiple forms of pathologies. A transversal rationality model is applied merging the complexity and divergence of cross-disciplinary and intradisciplinary approaches between missional theology, practical theology, contextual theology, religious pedagogy and ethics. Practical theology in South Africa should be applied from and within the contemporary socio-economic, systemic and ecclesiological pathologies.

Solidarity, prayer, and martyrdom add up to a time of salvation and judgment, a time of grace and stern demand - a time, above all, of hope.

(Gutierrez 1983:25)

\section{INTRODUCTION}

The objective of this article is not just the reconstruction of pastoral theology and practices, but the deconstruction of pathological ecclesial and socio-economic systems through a hermeneutical methodology of liberation (Patton 1988:31; cf. Wilson \& Ramphele 1989). The theological contributions of reflective practitioners during the late 1970s and 1980s and in recent literature are viewed and applied in an attempt to 'drink from our own wells' (Gutierrez 1983). Dreyer (2010:1) questions where we are heading as practical theologians in South Africa. This question does not refer to the strengthening of our disciplinary identity, but whether we are actually fulfilling our role in our context. A cross-disciplinary approach as an 'interacting network' of both scientific and non-scientific approaches (Osmer 2008:170ff ${ }^{1}$ and an intradisciplinary approach (Van der Ven 1994:2ff), instead of an exclusive interdisciplinary scientific approach, will be applied in search of constructive change in church and society (Dingemans $1988: 83,91) .{ }^{2}$ Suffice it to argue that practical theology is 'deeply contextual in terms of ecclesial, social, cultural interconnections, relationships and systems' (Osmer 2008:17). The different disciplines, in this article, represent networks that transverse one another in sharing common epistemological resources. The objective is to engage pastoral ministry ${ }^{3}$ within poor families and communities' specific cultural and contextual settings. Transversal or 'overlap and divergence' will arise through concrete reflection on the particular contexts of poor families and communities (Osmer 2008:172).

Historical and contemporary ecclesiological and socio-economic challenges frame the context of this article. The pastoral theology of Louw, in the Dutch Reformed Church, is outlined. Missional pastoral ministry in the Black church is discussed; the role of religious pedagogy as a transversal model is illuminated and pastoral ethical engagement with pathological socio-economic, political and ecclesial conditions is proposed. The conclusion integrates the key constructs of the article.

\section{INSTITUTIONAL METHODOLOGIES ENGAGING CONTEXTUAL CHALLENGES}

Practical theology as a crisis science highlights the dwindling authority of Scripture, church and leadership in revealing a growing discontinuity between church and society (Heitink 1993:15). Theology should respond to the 21st century challenge of a changing culture (cf. Bosch 2005; Guder 1998; Keifert 2006; Roxburgh 2005). Few traditional churches have transformed and instead became functional poststructuralists (henceforth missional). ${ }^{4}$ The majority of churches remain stuck in their structuralist ${ }^{5}$ (henceforth maintenance) paradigms (cf. Keifert 2006) and have capitulated into pathological systems and praxes. These ecclesiologies cannot adequately address the plural and multifaceted challenges of

1.Osmer (2008:170ff) prefers the concept cross-disciplinary dialogue instead of Van der Ven's (1994:6ff) multidisciplinarity or interdisciplinary approaches.

2. The concept interdisciplinarity refers to a 'real discussion between theology and social sciences'. The term intradisciplinarity highlights a new relation between the two sciences. The reason for Van der Ven's (1994:2ff) new approach lies in the fact that the social sciences do not perceive religion as part of the social reality and social sciences, especially within a secularised society. Practical theologians should integrate the methodologies of the social sciences in relation to practical theological questions and aims - in a concerted effort to 'drink from our own wells' (cf. Dingemans 1988:91ff).

3.Pastoral ministry in this article refers to a 'broader' perspective on pastoral care and counselling.

4. The concept missional is applied in reference to the critical response of contemporary Christianity to the traditional maintenance ecclesial paradigm.

5.This refers to the 'scientific revolution' that informed European comprehension that everything in the universe could be discovered by the laws (structures) that govern all physical phenomena (Thomas 2002). 
the 21st century, particularly the conditions of poverty-stricken families and communities. The predicament of maintenance ecclesiologies is apparent in its inability to relate the church's ministry to a changing culture, particularly pathological socio-economic conditions. The problem with maintenance ecclesiologies lies in its inability to support and energise its core ministries, such as pastoral ministry. Pluralism, multiculturalism increasing levels of poverty, crime, xenophobia, alcohol and drug abuse and the HIV and Aids pandemic exacerbates the church's challenges.

The inability of maintenance churches leads to various pathological psychosocial, systemic and socio-economic dysfunctionalities. Compassion fatigue, for example, among ordained and lay ministers is a direct result of the aforementioned (Böhmer \& Spangenberg 2001; Swart, Fourie \& Scheepers 2001). Compassion fatigue leads to a disempowering fatigue syndrome among church members and ministerial systems, which ultimately impacts on the needy and vulnerable. The article 'The Aids fulcrum: The church in Africa seesawing between alienation, estrangement, prejudice and love' substantiates this argument and contextualises it within the Africa context (Brown \& Hendricks 2004). The aforementioned holds that the church has 'missed its mark' and has instead created the perception of being 'cold, judgemental, uncaring and unloving'. Buffel (2006:1) contends that 'the church has failed to position itself in line with the true nature of the church as the body of Christ', with its inappropriate response to HIV and Aids.

The problem of the church's response to contemporary issues lies in its maintenance paradigm. Christendom (Keifert 2006:30-31), the inculturation of Christianity into Western culture, with its modern scientific method, has influenced and structured the church in such a way that the church has lost its missional identity and ethical pedagogical character. Diatesda Oiknonia (2004) (a community service for wellness through a caring community; henceforth Diatesda) in the Western Cape, which was founded in 1994 as a witnessing instrument of God's praxis, had to sever its links with a church that defaulted to a maintenance paradigm. Ministry on the margins ${ }^{6}$ become a meaningful encounter: 'What pastors lost in hierarchical authority, they gained in access to everyday experiences and problems of ordinary people' (Osmer 2008:19). Boff $(1986: 12,33)$ refers to the prefiguring of a new social structuring of the church from a juxta modum (emerging) basic church communities perspective. A quaestiones disputatae (critical reflective) approach urges contextualisation, theologically sound churches and the reinvention of hope-giving ministries (Boff 1986:46-47). Life in Latin American was (and may still be) saturated with socioeconomic and political questions and different perspectives. However, the bipolarity between 'impasses and new pathways, with suffering and hope' reveals the mystery of life within God's praxis (Gutierrez 1983:25).

\section{PATHOLOGICAL SOCIO-ECONOMIC CONDITIONS}

Pathologies faced by families or communities in poor local communities are complex and virtually non-transformational; 'confronted with so much evil, deeply destructive of the human personality' (Coene 1983:950). The church ought to be critical of the socio-economic and political conditions that oppress and dehumanise God's people and create enormous crisis situations for Black people ${ }^{7}$ (Moila 1989:208). A radical position is required in refusing to accept what Freire defined as (1978:9) 'packaged or prefabricated solutions'. The church should, for example, call local governmental structures to task in providing transparent and quality services (cf. the Confession of Belhar in Botha \& Naudé 1998).

6.Compare 'Missional encounter of the Gospel engaging cultural edges as agents of adaptive change' (Dames 2008).

7.The term Black people will be applied in this article to refer to so-called Coloured and Black people in South Africa.
South Africa's liberation movement of the 1970s, 1980s and 1990s achieved only political freedom. 'White monopoly capital' continues to hold economic power while poverty, unemployment and inequality are predominately confined to the Black majority (Cloete 2007:3). The new democratic South Africa does not resonate with the ideals of the Bill of Rights and the Constitution, regarding a free, fair, equal, non-racial, non-sexist and righteous society. Similarly, the Confession of Belhar was not allowed to foster a unified church or society for social and economic righteousness (Botha \& Naudé 1998; Strauss 2005). The reproduction of hegemonic philosophical and theological apartheid praxis disempowers authentic denominational and socio-economic transformation (cf. Van Dijk 1993). The greatest challenge for all South Africans lies in the appropriate readdressing of poverty and the quality of transformation (Sampson 2009:134). Superficial attempts by anyone to address these conditions should be viewed with suspicion. Social projects of some White churches may be equated to an attempt to silence a guilty consciousness for the inhuman apartheid atrocities. White communities benefited from the liberation movements' political achievements through retaining key economic power and demographic privileges. New guises of economic superiority and the perpetuation of old imbalances are prevalent today. Property and economic development lures poor families and communities to sell their properties for redevelopment in favour of White families. Socio-economic conditions of families in poverty-stricken communities remain unchallenged with little hope for its transformation - these communities remain trapped as victims (Sampson 2009:135). Shabodien (2007:1) highlights this fact in referring to farm workers in the Western Cape as the most marginalised communities in South Africa - with 'weak historical, social and political capital as a demographic group'.

Politicians, academics and public officials and the established churches of South Africa have become silent and allowed these disparities and gross discriminatory and disempowering practices to exists and grow. Shabodien (2007:1) criticises politicians in the Western Cape for a lack of land reform due to their reluctance to 'tamper with this important sector for fear of declining provincial revenues'. It is destructive and breeds the old oppressive practices, which do nothing but exacerbating the plight of poorer communities. Freire (1978:3) therefore called for the death of self-interest and 'to die as a class' in being reborn in consciousness.

Some of the traditional churches in South Africa demonstrate an inability to 'be reborn in consciousness' and to 'die as a class'. Furthermore, the uncertainty and corruption brought about by South Africa's political transition, globalisation and postmodernity breed fundamentalism and individualism to the extent that a vision for the common public good of all suffers. The dilemma is that deep levels of distress develop among the majority of the poorest in the broader community. Pastoral counsellors may consequently encounter people with anxieties that do not stem from their personal lives, but from a 'distress-effect' in the broader community (Taylor 1984:229). The impatience of the poor has brought the need for poverty alleviation into sharper focus. This calls for a new focus in government in addressing poverty alleviation before reconciliation (Sampson 2009:141). It also calls churches to realign their programmes for reconciliation and restitution in redressing socio-economic conditions in poverty-stricken communities. The plight of poor communities from the health profession's perspective is self-illuminating:

8.The Confession of Belhar publicly witnessed against an unjust system; cultivating a culture of change and may continue to be instrumental in the transformation of unjust and irreconcilable contemporary practices (like the HIV and Aids scenario) and cultures. This public missional witness, however, has lost its momentum, leaving the church in South Africa in the same disposition as Christendom worldwide ['collapsing into modernity', cf. Smit 2007]. A key answer to this dilemma for the church today lies in her 'being' missional and in attending to the lives and condition of the vulnerable, less fortunate and poor on the periphery of society (Dames 2008:60).

9.Suffice it to say that there are many churches that want to do something about it, but that they do not always know what to do or how to go about it (Taylor 1984:228). 
In our country, the consequences of extreme levels of poverty and interpersonal violence bring people to the doors of our public health facilities. [This is the] end result of desperate lives leading to stabbings, gunshots, rape victims, gangrene from disease and personal neglect, ulcers from drug abuse, homeless people exposed to the cold, shack dwellers burnt at paraffin stoves, young children suffering the end results of malnutrition, cancers from smoking, asbestos, poor diet and of course our latest epidemic, HIV and Aids.

(Cairncross 2007:1)

The church is strategically positioned to make a difference as it possesses two assets, namely premises in all the stricken areas and counselling skills that transcend cheap information and advice (Taylor 1984:228). Research has highlighted the existence of a link between economic and pathological factors (Taylor 1984:231). Such a finding may be helpful in constructing a picture of the severe effects of the socio-economic dynamics in local poor communities. Gangsterism, for example, is a phenomenon that links economic conditions with pathological factors (Dames 1999:3; MacMaster 2003:61-66, 69; Pedro 2001:44).

The church is not responsible for comprehensive solutions to these intractable problems. However, these problems cannot entirely be absolved from the responsibility for the socioeconomic distress that local poor families and communities are experiencing. The church remains a contrast community and a catalyst for socio-economic transformation (Osmer 2008:192). The pastoral task demands a theological re-evaluation of its traditional position of an uncritical theological undergirding to the norm of a 'work ethic' or 'work' as such. The nature of work for poor and vulnerable families, particularly within a gangster ecosystem and with reference to the 'dop' system on farms, through which people are supposed to find dignity, status and purpose, is degrading and dehumanising. It generates new forms of poverty, injustice and exploitation, the loss of identity, anxiety, strained relationships and meaninglessness (Taylor 1984:231-232). Families in these communities learned how to survive with human dignity and integrated valued and purposeful lives. These families are living signs of hope in fostering a kairos moment, a time of transformative opportunity (Taylor 1984:232). Their world views should be acknowledged and may demonstrate practical signs of the eschatology. This is where pastoral counsellors should come to 'die as a privileged class' in learning with and from families and communities within their pathological conditions. Contextual practical theology for social transformation is yet again of paramount importance (Cochrane, De Gruchy \& Petersen 1991).

Two different pastoral approaches are now viewed to reflect on how contemporary pastoral challenges are met.

\section{PASTORAL THEOLOGY IN THE (WHITE) DUTCH REFORMED CHURCH IN SOUTH AFRICA}

Cura animarum, the care of human souls, informed and shaped pastoral theology in the Dutch Reformed Church of South Africa (DRCSA) in recent decades (Louw 2004:1). Dingemans (1996:86) rightly locates Louw, as representative of the DRCSA's pastoral theology, within the individual paradigm. Louw (2008), however, may have shifted recently to include a 'wider community' focus. He focuses on the human search for meaning and spirituality in a postmodern society. However, contemporary socio-economic and ecclesial challenges pose critical questions to scientific and epistemological attempts in defining and informing pastoral praxes. A hermeneutical approach in facilitating only an interpretation for and about human existence within the 21st century context could prove to be insufficient. Freire (1978:24) argued for a hermeneutical reading within social contexts. Louw (2004:1) applies four movements in pastoral theology, namely the specific hermeneutical process that takes place in the pastoral encounter; the implications of salvation for individuals in their social context; the methods used in pastoral counselling; and the ultimate healing or therapeutic effect of pastoral intervention. A fifth aspect should be added, namely a methodology for the deconstruction of pathological socio-economic, cultural, political and maintenance ecclesiological systems. The application of such a deconstruction methodology should function as an empowering process in the liberation from such pathological systems. A social contextual hermeneutical (critical actionreflection-action) approach by poor families and communities in pastoral ministry should be applied.

Socio-economic pathologies engender and perpetuate poverty, violence, alcohol and drug abuse and oppression. These crises pull the church from its traditional and sometimes privileged position to the margins of disempowerment and even systemic dysfunctionalities (Dames 2007, 2008). However, the dynamic between existential realties and God's praxis lies at the heart of the quest for a relevant pastoral theology. Pastoral theology could therefore be defined as an existential action and reflection encounter between God, human beings and the environment (cf. Freire 1978:57).

It is not only individuals but whole communities that have to deal with challenging life issues (cf. Louw 2004:3, 2008:63). The existential reality of dysfunctional systems exacerbates these threats. A pastoral hermeneutical and cura vitae methodology may fall short in addressing the harsh realities of poor families and communities (Louw 2004:3-4, 2008).

A theology 'from below' and an 'existential locus of Godlanguage' (Braaten 1989:19, cited in Louw 2004:4) should operate within 'the overall plan for the society' (Freire 1978:89). Liberation and especially transformation are of crucial importance for tangible change. Pastoral ministry as action-reflection-action science mediates the Christian faith in the praxis of society towards the transformation of these praxes (Heitink 1993:18).

Pastoral hermeneutics is a critical action-reflection-action process on how to shape faith practices in transforming lifethreatening contexts (Louw 2004:5). Meaning making and identity formation cannot only focus on a mature faith, but ought to engender ethical practices. Contemporary pastoral ministry should function within community contexts with multiple existential threats. The realisation of any telic ${ }^{10}$ pastoral ministry model may foster individual piety instead. Heitink's (1979) bipolarity thesis is of significance in its ability to juxtapose complex and opposing issues, for example personal spirituality and contextual solidarity for liberation.

The basic assumption of pastoral ministry is to change, comfort, sustain, guide, support and heal people as well as their communities (Louw 2004:7). Pastoral ministry as promissio therapy should not only focus on God's fulfilled promises (2004:7); it must also engage existential pathologies in terms of God's praxis for liberation. Promissio therapy distinguishes pastoral therapy from non-theological therapies and holds the potential to address critical existential human issues. Liberation therapy refers to liberation and transformation of existential and systemic pathologies. The uniqueness of pastoral ministry lies in its ability to provide transcendental and immanent hope for liberation (cf. Louw 2004:7). Promissio therapy offers meaningimparting values. Liberation therapy seeks liberation practices and fosters values such as ethics, righteousness, reconciliation, reconstruction and the deconstruction of systemic pathologies. An eschatological, liberation and pneumatological perspective informs pastoral ministry (Louw 2004:8).

The notion of cura vitae becomes important for any pastoral theology that seeks to offer meaning and liberation. Existential challenges, such as socio-economic oppression, crime, HIV and

10.'Telic is derived from the Greek term teleion which, in Scripture, denotes the task of preparing one to appear before, and to live in, God's presence. The term teleison also encompasses the idea of a mature faith and spirituality' (Louw 2004:7). 
Aids and xenophobia could be addressed by a pastoral approach that acknowledges the liberation of pathological conditions from the perspective of the healing of life (Louw 2008:11). Cura vitae is a Christian spiritual and contextual embodiment of contemporary existential life for its liberation and the healing of life. Louw (2004:12) argues that the question in suffering is not whether you have suffering, but how you live your suffering. The mere 'experiencing' of suffering can be destructive and inhuman. Pathological socio-economic paradigms and practices render the notion to 'live your suffering' as an ideal. The ability to live suffering is a question of human and community dignity, or survival. There is no dignity in pathological socio-economic conditions (Ehrenreich 2007). The objective for pastoral theology in contemporary South African communities is to empower people with more than just 'a vivid hope that fosters meaning and significance in life' (Louw 2008:16). Louw attempts to correct his position by opting for a pastoral ministry of affirmation $(2004: 16,30)$. However, the question remains as to how one can be affirmed within a pathological system that threatens and drains the very life and moral fibre of struggling families and communities.

Louw (2008:18) applies ontology ${ }^{11}$ in informing meaning and significance to the being functions of persons. Socioeconomic being-functions of poor families and communities should form part of such an ontological perspective! Jesus' incarnation of the word of God undergirds the essence of the pastor's concrete being for God in pathological realities of life (Simmons 1989:519). Pastoral ministry of affirmation as ontology reconstructs the being status, dignity and identity of human beings (Louw 2008:30-32). Pastoral ministry as empowerment should incorporate a Christological and reconstruction (Botman 1993) and fortological ${ }^{12}$ perspective (Louw 2008:31). The value of fortology lies in its redefinition or reconstruction of pathologies for transformational, empowerment, growth and healing possibilities. Fortological empowerment is crucial for missional pastoral ministry, especially in recurring and persisting pathological socio-economic contexts (cf. Louw 2008:31).

\section{MISSIONAL PASTORAL MINISTRY IN BLACK COMMUNITIES}

Missional theology is instrumental in attending to environmental, socio-economic and political challenges (Ballard \& Pritchard 1996:3, 23). Missional pastoral methodology bridges the gap between a pastor-client approach and liberation pastoral ministry (Johnson 2004:480). Contemporary pastoral ministry is embedded in an individualised pastoral focus within a 'crisis' maintenance paradigm that can only be addressed through the continuing conversion of pastoral theology (cf. Guder 2000:150). Missional pastoral ministry is shaped by its role in God's mission. The transformation and healing of a broken world is the objective - restoring it to God's ultimate vision for the world (cf. Barret et al. 2004:x). The missional ${ }^{13}$ pastoral vocation and ethos of the church should embody everything the church is and does. Pastoral theologians should review their ecclesiological presuppositions (Bosch 2005:370). Research indicates that some of the poor Black and White church communities in Southern Africa seem to be more 'missional' than some of their more affluent 'White' counterparts (Van der Walt 2007). Our recent liberation struggle for democracy schooled Black churches in being missional (Institute for Justice and Reconciliation 2004). Missional churches present a critical approach towards their surrounding contexts. It engages actively with faith and

11.'Ontology is taken to mean a hermeneutical endeavour ... to link God to human life in order to deal with the spiritual dimension of significance and the question of the ultimate meaning of life in the face of evil and suffering' (Louw 2008:18).

12.'Fortology represents a movement away from pathology to constructive enforcement and encouragement' (Louw 2008:31) [see Strümpfer 2002].

13 'The missional model has the potential to turn the churches inside out rather than allowing them to focus inward thereby overlooking the human situation' (Johnson 2004:477). existential issues through reciprocal partnerships within the praxis of the Trinity (Marais \& Taylor Ellison 2008). ${ }^{14}$

Partnerships for missional pastoral ministry in Black communities refer to a systems approach in which congregations cluster together in their missional vocation (Wepener 2003:8). The following two distinctive models are self-explanatory:

- Sister Simonne Coene of the International Catholic Mission's Clinical Pastoral Education (CPE) led supervisory training in Manila's Makati Medical Center in the Philippines. This hospital is a good example of the church's ability to create partnerships for missional pastoral ministry in pathological contexts (Coene 1983). CPE is a relevant clinical missional pastoral ministry in focusing on the existential crisis of the poor:

... the poor are ultimately the privileged community and agents of salvation [ministers?!] ... the Church does not merely work for the poor in the manner of a beneficent institution but more so with [CPE!] the poor, sharing their life and their aspiration, knowing their despair and their hope, walking with them in their search for authentic humanity in Christ Jesus ...'

(Coene 1983:91-92)

The core methodology of CPE is learning from the human document of persons in crisis'. Coene works in a squatter or informal settlement. She observes that crisis is economic - poverty and its gruesome consequences: hunger, sickness, landless, homeless. [T]he poor are trapped in a vicious circle, grappling with moral, social, physical crises ...' (Coene 1983:92). The impact and levels of economic crisis should not be underestimated in relation to communities, families and social systems.

- Wimberley (1979) offers practical pastoral engagement with the 'human document of persons in crisis' ${ }^{15}$ Communal $^{16}$ pastoral ministry generates the total caring resources (worship, church administration, preaching and teaching) as the 'dominant concern' of the church in caring for persons and families in crisis:

'Pastoral care exists when the hungry are fed, when the naked are clothed, when the sick are healed, when the prisoners are visited' (Wimberley 1979:18). Healing, reconciliation, sustaining and guiding functions characterised pastoral care historically. Wimberley (1979:19-20) focuses only on the last two functions, which dominate pastoral care in the black church. Reconciliation occupies a secondary position, while healing became difficult because of the racial climate. The sustaining function enables families in crisis 'to transcend and endure conditions that are not immediately alterable.

(Wimberley 1979:20)

The guiding function helps families in making informed choices and in acting on it. Wimberley focuses also on the choices families make in coping with crises. The prophetic presence of Christians and pastors in crisis situations of victims characterises pastoral ministry (Moila 1989:205-206; Dames 1999:3; MacMaster 2003:61-66, 69; Pedro 2001:44). The symbolic significance of Black pastors is revealed in the manner in which they engage in and through the functions of sustaining and guiding (Wimberley 1979:20).

Pastoral ministry is called upon to engage in eco-systemic liberation: 'Racism and oppression have produced wounds in the Black community that can be healed only to the extent

\footnotetext{
14.Compare Bosch (2005:370).

15.'Many persons may have the impression that pastoral care does not exist in the Black church [in South Africal because very little has been written about it. ... [l]t can be concluded that pastoral care has always existed in the Black church because the needs of persons are ministered to by others all the time' (Wimberley 1979:17-18).

16.Compare Heitink's (1979:375) pastoral care model 'in fellowship with the Church of Christ'.
} 
that healing takes place in the structure of the total society' (Wimberley 1979:21). Such liberation is justifiable: 'For the slave, healing meant liberation from oppression; therefore, it was impossible to repair the damage done by slavery without manumission (freeing/freedom)' (Wimberley 1979:29). The ecumenical movement in South Africa was and is still confronted with the anger of Black and the fear of White people. Pastoral facilitation of confession, restitution and reconciliation remains crucial today (Botman 1993:34).

Black pastoral ministry differs from pastoral care in White mainline Protestant churches (Wimberley 1979:22): 'Psychotherapists [and pastoral therapists] often have difficulties in relating to and understanding clients who are socio-economically and culturally different' (Wilson \& Lyles 1984:133). Healing has been the dominant pastoral function in traditional White churches ${ }^{17}$ due to the absence of economic, political and social oppression.

However, Black pastors have persistently demonstrated a rare creativity in meeting the needs of families, whilst pastoral care and counselling of White churches was inadequate in providing communal pastoral ministry (Wimberley 1979:23). The Black church utilised significant supportive resources in enabling families to overcome and endure life crises exacerbated by oppression (Wimberley 1979:23-24, 27). Black churches became an alternative society as a community resource in sustaining Black families' self-esteem in the midst of powerlessness, whilst substituting families for economic and political participation in the wider society (Wimberley 1979:30). The need for a prophetic missional ministry in the Black church has become urgent again (Wimberley 1979:34). The transformation of pathological socioeconomic and systemic factors in society is part of the church's mission (Wimberley 1979:92).

The time is ripe for the missional ministry of the Black church to readdress socio-economic and political pathologies that inhibit psychosocial and economical development of poor families and communities (Wimberley 1979:92-93). 'Changes in the structures of our economic relationships will lead to changes in social relationships; and in all this the churches have an important part to play' (Taylor 1984:229). The Black church should engage in influencing government policies in ensuring job creation for the poor, job skills training and economic security. Parental energy and time constrains are transformed into pedagogical and wellness spaces. Parental energies can thus focus on creating atmospheres of support for their children in developing a basic sense of trust and security (Wimberley 1979:93).

The pastoral ministry models of Louw, Coene and Wimberley could inform a missional approach to transform disempowered ecclesial systems. The empowerment of pastoral ministry within and outside the church becomes crucial in addressing pathologies. Keifert's (2006:48-50) diffusion-of-innovation methodology in transforming the culture of maintenance churches provides a possible solution (future research should attend to this aspect). The objective in this article is to arrive at an appropriate innovation for missional pastoral and ecclesial systemic transformation. Empowerment for meaningful, soulful life care and total liberation is urgently required for suffering families and communities.

\section{A TRANSVERSAL MODEL OF CROSS-}

\section{DISCIPLINARITY: TOWARDS A PASTORAL PEDAGOGY FOR EMPOWERMENT}

This article embodies an 'interacting network' of different scientific and reflective practices. It 'presupposes a more fluid and dynamic understanding of the relationship between

17. … healing could become a tradition in the mainline Protestant white churches because there were economic resources to provide clinical training for pastors, whereas the Black church had to rely upon a tradition of sustaining and guiding fashioned in response to oppression' (Wimberley 1979:22-23). the [different] dissiplines' (Osmer 2008:172). Ploeger (1995) represents a bipolar 'interacting network' between theology and the general sciences. He applies a reciprocal and circular pedagogical methodology in analysing philosophical foundations and relations between social sciences. The dynamic interaction between religious and social pedagogy characterises his methodology (Dames 1989:169-172). Ploeger's (1995:59, 150) 'three plus one' spiritual-diaconal methodology is an example of a transversal rationality model intersecting with missional pastoral ministry for liberation (cf. Osmer 2008:170-173). Ploeger's objective is the emancipation of citizens, the poor and wealthy (old and young) within psychosocial relationships (Heitink 1993:258). Freire's (1973:57-66) hermeneutics of conscientisation in promoting the well-being of oppressed and suffering people towards a praxis of total liberation corresponds with Ploeger's objective. Transversal hermeneutics converges epistomology (the Bible, Christian tradition, pastoral ministry and faith experience), social life (social behaviour and socioeconomic praxis) and personal formation and existential experiences and needs (Ploeger 1995:111, 117). 'Plus one' focuses on action learning and critical reflection on that action (Lanservan der Velde 1995:4).

Struggling families and communities need to be guided to a better comprehension, liberating action and appropriate ethical discernment regarding existential socio-economic and systemic pathologies (cf. Ploeger 1995:62). The spiritualdiaconal methodology fosters ethical values such as solidarity, independence, responsibility and self-suffiency. Reciprocal socio-economic and political learning fosters the formation of new meaning and engenders liberating practices in transforming pathologies (cf. Ploeger 1995:59, 216-220). Reciprocal hermeneutics, according to Freire (1973:54-55, 72ff), informs an emancipation methodology towards a praxis of freedom. Critical hermeneutical and communicative action (Ploeger 1995:333339) undergirds eco-theology (Boff 1986) ${ }^{18}$ which is crucial to discern and inform the authentic existential experiences of poor families and communities in relation to God's praxis (Dingemans 1996:90). Schrage (1988:83) underlines the fact that ' $t$ t]he neighbour in need is the only place where we find God in the world'. Ploeger's methodology could be instrumental for missional pastoral ministry, especially in contemporary local and national contexts, by empowering families and communities in their socio-economic distress (Moila 1989:198). Missional pastoral ministry from a pedagogical perspective forms empowered, liberated, well-integrated and functioning families or communities (Wimberley 1979:78-79; cf. Conyne 2004).

Müller (2005:73) holds that pastoral theology 'happens whenever and wherever there is a reflection on practice, from the perspective of the experience of the presence of $\mathrm{God}^{\prime}$. The moment of praxis is 'always local, embodied and situated' (Müller 2005:73). ${ }^{19}$ The 'local and informal levels' in pastoral theology refers to a rediscovery of the basic forms of pastoral theology as being reinvented as postfoundationalist ${ }^{20}$ (Müller 2005:74; cf. Boff 1986). However, in the context of this article, a new praxis, ${ }^{21}$ namely missional contextual pastoral theology for liberation, is preferred (cf. Boff 1986:32). Missional pastoralpedagogical ministry requires ethical leadership that transforms individualised needs and institutional agendas (cf. Botman 1993:5). It focuses intentionally on the collective responsibility

18.Boff (1986) introduced a new theological methodology, namely eco-theology, in an attempt to bring the 'experiences of people' in relation with the official theological discourse of the church (Dingemans 1988:90).

19 'With all the emphasis, and justly so, on the scientific quality of [pastoral theology] a disregard has developed for the many levels and various forms of the practice of [pastoral theology] on the local as well as informal level' (Müller 2005:73).

20.A postfoundationalist or poststructuralist approach departs from a predominantly maintenance (structuralist or foundationalist) paradigm. 'This perspective takes seriously the challenges of postmodern thinking to all totalizing, modernist attempts to secure true knowledge through foundationalist strategies. It acknowledges that knowledge is constructed on the basis of social practices, language, and values that are local and contextual' (Osmer 2008:308ff).

21.'The basic church communities are helping the whole church in the process of declericalization, by restoring to the People of God, the faithful, the rights of which they have been deprived in the linear structure' (Boff 1986:32). 
for the common good of entire communities (Freire 1978:8). Missional pastoral ministry within communities should co-exist in a 'delicate tension' within appropriate ethical principles and practices in fostering the spiritual and civic virtue of authentic transformational leadership: 'We have a responsibility to contribute to the "common good" in our contexts ...' (Dreyer 2010:3). Missional pastoral-ethical leadership should become a prerequisite in pastoral theology (cf. Bellah et al. 1988, cited in Bass \& Steidlmeier 1999). Maintenance pastoral ministry is called to repentance and total obedience 'grounded in a spirituality of servant leadership', embodying its mission as a sign and witness of God's grace and self-giving love (Osmer 2008:29). This is a crucial ethical question, specifically in the light of the pathological conditions that poor and vulnerable families and communities have to endure. Such obedience implies a responsibility and demands a comprehensive new attitude of repentance, conversion, a change of course and a new orientation (Botman 1993:102ff; Schrage 1988:40-41).

Coene's work is, therefore, a fascinating and inspiring example of how a clinical methodology could be transformed to fit the needs within pathological contexts (Coene 1983:90, 92). Her being with poor people and listening to their needs was her way of

allowing [her]self to enter deeply into their lives (pains, joy)', making herself vulnerable by reaching them in 'situating [her]self among them with an attitude of openness, listening, empathy and compassion ... to read below, deep below the surface of the reality of a people living in a depressed area, wrapped in a "culture of silence ... I learned to enter into the mystery of incarnation and understand the poverty-stricken people from within.

(Coene 1983:92, 95-96, 97)

The Diatesda model was founded as a pastoral response to pathological socio-economic challenges. It fostered a communal pastoral ministry for church members and more importantly for the broader community. Diatesda became an integrated, multifaceted and cross-disciplinary pedagogical and missional pastoral ministry. It could be concurred that it became 'involved in the Black community's fight for economic and political lobbying, community organization around selected issues, [the Reconstruction and Development Programme], sponsorship of economic ventures, and other means' (Wimberley 1979:94). Diatesda initiated and continues to create an environment vital for growth in a community facing recurring and persisting existential socio-economic pathologies. It has become a missional communal place and space of soul care, life healing, liberation and transformation - without the church!

Spendthrift generosity (the giver's own blood) brought fruition to the oppressed people of Latin America in confronting their institutionalised churches. It was a 'demanding, but at the same time, most promising moment in its history' (Gutierrez 1983:25). Political oppression in Southern Africa's recent history caused enough bloodshed. Any form of socio-economic and cultural oppression or suffering today should be rejected. Practical theology should be a reciprocal process of reflecting on the Praxis of the Trinity in and through the transformation of the church's praxis towards the liberation of the world's praxis (Dames 2009:84)

\section{CONCLUSION}

Pathological conditions remain a way of life for most of the poverty-stricken families and communities in Southern Africa. Missional pastoral ministry should engage in the liberation from and transformation of pathologies in the daily lives of suffering families and communities. Liberation 'from below' proposes to transform oppressive conditions into God's preferred praxis of total liberation:

Prophets need not advocate a revolution to overthrow an unprincipled regime. Commitments to a new understanding [how to live and transform suffering] undermine the allegiances to old realities and assure the collapse of [pathological socio- economic, political and even ecclesial] structures that are at odds with the new vision.

(Simmons 1989:521)

Christians are to be signs of hope, salt and light in the world, pointing to the moral influence that should be exercised in transforming pathologies, deconstructing and reconstructing public policy and ecclesial maintenance they ought to be guided and sustained by a commitment to justice, human rights, dignity and religious liberty, which is conspicuously absent from Christendom's moral priorities..$^{22}$

\section{REFERENCES}

Ballard, P. \& Pritchard, J., 1996, Practical theology in action: Christian thinking in the service of church and society, SPCK, London.

Barret, L.Y., Guder, D.L., Hobbs, W.C., Hunsburger, G.R., Stutzman, L.L., Van Kooten, J. \& Ziemer, D.A., 2004, Treasure in clay jars: Patterns in missional faithfulness, Eerdmans, Michigan.

Bass, B.M. \& Steidlmeier, P., 1999, 'Ethics, character, and authentic transformational leadership behaviour', The Leadership Quarterly 10(2), viewed 10 February 2010, from http://web.ebscohost.com.ez.sun.ac.za/ehost/

Boff, L., 1986, Ecclesio-Genesis: The base communities reinvent the church, Collins, Glasgow.

Böhmer, A.C. \& Spangenberg, J.J., 2001, 'Depressie en angs onder predikante van die Nederduitse Gereformeerde Kerk in die Wes- en Suid-Kaap [Depression and anxiety among ministers of the Reformed Church in the Western and Southern Cape]', Nederduitse Gereformeerde Teologiese Tydskrif $42(1 \& 2), 6-14$.

Bosch, D., 2005, Transforming mission: Paradigm shifts in theology and mission, 12th edn., Orbis Books, New York.

Botha, J. \& Naudé, P., 1998, Op pad met Belhar: Goeie nuus vir gister, vandag en môre [On the road with Belhar: Good news for yesterday, today and tomorrow], Van Schaik, Pretoria.

Botman, H.R., 1993, 'Discipleship as transformation? Towards a theology of transformation', unpublished doctoral dissertation, Department of Systematic Theology, University of the Western Cape.

Brown, J. \& Hendricks, H.J., 2004,'The Aids fulcrum: The church in Africa seesawing between alienation, estrangement, prejudice and love', Practical Theology in South Africa 19(2), 19-36.

Buffel, O., 2006, 'Pastoral care to people living with HIV/Aids: A pastoral response that is contextual and liberating', Practical Theology in South Africa 21(1), 1-18.

Cairncross, L., 2007, 'The Challenge of Health Inequality between the Private and Public sectors', Conference of the Ethical Leadership Project, 2007 proceedings, Bellville, South Africa, September 06-07, viewed 03 November 2007, from www.elp.org.za

Cloete, K., 2007, 'Bridging inequality: Race, class, cultural differences and poverty in the Western Cape. A South African Communist Party perspective', Conference of the Ethical Leadership Project, 2007 proceedings, Bellville, South Africa, September 06-07, viewed 03 November 2007, from www.elp.org.za

Cochrane, J., De Gruchy, J. \& Petersen, R., 1991, In word and deed: Towards a practical theology of social transformation, Cluster Publications, Pietermaritzburg.

Coene, S., 1983, 'Clinical pastoral education with the poor', The Journal of Pastoral Care XXXVII(2), 90-97.

Conyne, R.K., 2004, Preventive counselling: Helping people to become empowered in systems and settings, Brunner-Routledge, New York.

22.Neuhaus holds that the 'debate within and amongst the churches is no longer over whether religion should be politically relevant. The debate is about the terms on whether religion should be politically relevant. The debate is about the terms on
which that involvement takes place. Which policies should be supported and why?' (Neuhaus 1987, cited in Simmons 1989:517) 
Dames, G., 1999, ‘Klein en groot kan nie meer goed en kwaad onderskei nie [Small and big cannot distinguish between good and evil anymore]', Ligdraer. Amptelike nuusblad van die Verenigende Gereformeerde Kerk in Suider-Afrika 60(5), 3.

Dames, G.E., 1989, 'n Studie van kategetiese modelle met spesifieke verwysing na die VGKSA (Kaapland) [A study of catechism models with special reference to the VGKSA (Cape)', unpublished doctoral dissertation, Department of Practical Theology, University of the Western Cape.

Dames, G.E., 2007, 'New frontiers for mission in a post-modern era: Creating missional communities', Missionalla 35(1), 34-53.

Dames, G.E., 2008, 'Missional encounter of the Gospel engaging cultural edges as agents of adaptive change', Practical Theology in South Africa 23(1), 55-79.

Dames, G.E., 2009, “'Quo vadis" Practical theology? A response', Scriptura 100, 81-88.

Diatesda Oiknonia, 2004, 'Annual Business Report, 2003-2004', unpublished report

Dingemans, G.D.J., 1988, 'Practical theology in the academy: A contemporary overview', The Journal of Religion, University of Chicago (76), 82-96.

Dreyer, J.S., 2010, 'Practical theology in South Africa: Recent developments and new challenges', paper presented at the annual meeting of the Society for Practical Theology in South Africa, University of Pretoria, Pretoria, 21-22 January.

Ehrenreich, T., 2007, 'Thirteen years after apartheid: The quest for democratic governance', Conference of the Ethical Leadership Project, 2007 proceedings, Bellville, South Africa, September, 06-07, viewed 03 November 2007, from www. elp.org.za

Freire, P., 1973, Pedagogie van de onderdrukten [Pedagogy of the oppressed], Baarn, Anthos.

Freire, P., 1978, Pedagogy in process: The letters to Guinea-Bissau, The Seabury Press, New York.

Guder, D.L. (ed.), 1998, Missional church: A vision for the sending of the church in North America, Eerdmans, Michigan.

Guder, D.L., 2000, The continuing conversion of the church, Eerdmans, Michigan.

Gutierrez, G., 1983, We drink from our own wells: The spiritual journey of a people, Orbis Books, Maryknoll.

Heitink, G., 1979, Pastoraat als hulpverlening: Inleiding in de pastorale theologie en psychologie [Pastoral care as aid: An introduction to pastoral theology and psychology], JH Kok, Kampen.

Heitink, G., 1993, Praktische theologie: Geschiedenis, theorie, handelingsvelden [Practical theology: History, theory, action fields], JH Kok, Kampen.

Institute for Justice and Reconciliation, 2004, Interfaith solidarity: A guide for religious communities, Amazon Media, Cape Town.

Johnson, R.W., 2004, 'Mission in the Kingdom oriented church'. Review and Expositor. Mission in the 21st Century 101(3), 473-495.

Keifert, P., 2006, We are here now: A new missional era. A missional journey of spiritual discovery, Allelon, Eagle, Idaho.

Lanser-van der Velde, A., 1995, 'Wederkerig Geloofsleren [Reciprocal learning to belief]', unpublished paper, Vrije University Amsterdam.

Louw, D., 2004, A pastoral hermeneutics of care and encounter, 5th edn., Lux Verbi, Wellington.

Louw, D.J., 2008, Cura vitae: Illness and the healing of life, Lux Verbi, Wellington.

MacMaster, L.M., 2003, "n Pastoraal-teologiese perspektief op trauma van gangsterism in die Kaapse Skiereiland', Praktiese Teologie in Suid-Afrika 18(2), 59-78.

Marais, F. \& Taylor Ellison, P., 2008, 'Push through the pain: The Spirit transforming churches across the world', a draft of early reflections on a narrative/ethnographic contextual model for the research of congregationsin conversation with a missional vision for the church, viewed 22 October 2010, from http://communitas.co.za/dienste/navorsing1/120ekklesiologiemissionere-gemeente-wees/273-push-through-thepain?q=push+through+p.
Moila, M.P., 1989, 'The role and the function of the pastoral counsellor in the present crisis in South Africa', Africa Theological Journal 18(3), 196-209.

Müller, J.C., 2005, 'A postfoundationalist, HIV-positive practical theology', Practical Theology in South Africa 20(2), 72-88.

Osmer, R.R., 2008, Practical theology: An introduction, Eerdmans, Michigan.

Patton, J., 1988, 'Pastoral ministry in a fractured world', The Journal of Pastoral Care XLII(1), 26-36.

Pedro, S., 2001, 'Gemeentewees in 'n geweldkonteks (Elsiesrivier)' [The church in a context of violence (Elsiesrivier)], Kruisgewys 1(1), 44-45.

Ploeger, A.K., 1995, Inleiding in de godsdienstpedagogiek [Inleiding tot die godsdienspedagogiek], Kok, Kampen.

Roxburgh, A.J., 2005, The sky is falling!?! Leaders lost in transition, ACI, Idaho.

Schrage, W., 1988, The ethics of the New Testament, Fortress Press, Philadelphia.

Shabodien, F., 2007, 'Transformation through land redistribution in the Western Cape', Conference of the Ethical Leadership Project, 2007 proceedings, Bellville, South Africa, September 06-07, viewed 03 November 2007, from www.elp.org.za

Simmons, P.D., 1989, 'The pastor as prophet: How naked the public square?', Review and Expositor 86(4), 517-531.

Sampson, C., 2009, 'Ethical leadership and the challenges of moral transformation', in G.E. Dames (ed.), Ethical leadership in and through politics, pp. 131-144, SUN MeDIA, Stellenbosch.

Strauss, PJ., 2005, 'Belydenis, kerkverband en Belhar [Confession, denomination and Belhar]', Nederduits Gereformeerde Teologiese Tydskrif 46(3\&4) September \& Desember, 560-575.

Strümpher, D.J.W., 2002, 'A different way of viewing adult resilience', paper delivered at the 34th International Congress on Military Medicine, Sun City, South Africa, 17 September.

Swart, T., Fourie, C.M., \& Scheepers, H.F., 2001, 'Aspekte van uitbranding by predikante van die NG Kerk in die Sinode van Suid-Transvaal (1997-1999): Enkele empiriese bevindings [Aspects of burnout in pastors of the Dutch Reformed Church in the Synod of Southern Transvaal (19971999): Some empirical findings]', Nederduitse Gereformeerde Teologiese Tydskrif 42(1\&2), 89-100.

Taylor, R.P., 1984, 'First aid in pastoral care: Pastoral care and high unemployment', The Expository Times 95, 228-232.

Thomas, L., 2002, 'Poststructuralism and therapy: What's it all about?', The International Journal of Narrative Therapy and Community Work 2, 85-89.

Van der Ven, J.A., 1994, Empirical methodology in practical theology: Why and how?, Lecture at the South African Academy of Religion, University of South Africa, Pretoria on 18 January 1994, pp. 1-19.

Van der Walt, P., 2007, 'Voices from clay jars: Reflections on the SAMPC reading team's reports', paper delivered at the Southern African Think Tank on Missional Theology and Praxis. In partnership with the Allelon International Mission to Western Culture Project, Stellenbosch University, Stellenbosch, 12-13 November.

Van Dijk, T.A., 1993, 'Principles of critical discourse analysis', Discourse E Society 4(2), 249-283.

Wepener, C., 2003, 'Missionêre kerk: Van sturend na gestuur' [Missional church: Sending to sent], Kruisgewys 3(2), 8-9.

Wilson, F. \& Ramphele, M., 1989, Uprooting poverty: The South African challenge, Creda Press, Cape Town.

Wilson, M.H. \& Lyles, M.R., 1984, 'Interracial pastoral counselling with Black clients', The Journal of Pastoral Care XXXVIII(2), 133-141.

Wimberley, E.P., 1979, Pastoral care in the Black church, Abingdon, Nashville. 